\title{
Menemukan Strategi Pengembangan Kawasan Industri Melalui Analisis Sektor Unggulan Kota Binjai
}

\author{
Dessy Eresina Pinem ${ }^{1}$ \\ Institut Teknologi Medan, Medan, Indonesia
}

Artikel Masuk : 9 Maret 2016

Artikel Diterima : 19 April 2016

Tersedia Online : 30 April 2016

\begin{abstract}
Abstrak: Sektor industri merupakan sektor andalan yang berpotensi menciptakan pertumbuhan progresif di sebuah kawasan. Pertumbuhan kawasan yang mengandalkan sektor industri didorong oleh penjualan hasil produksi, penyerapan tenaga kerja, dan efek pengganda lainnya sehingga banyak kabupaten atau kota di Sumatera Utara berusaha mengembangkan sektor ini. Industri yang dapat dikembangkan adalah industri yang sesuai potensi dan sumber daya lokalnya agar pertumbuhan kawasan menjadi optimal. Dalam RTRW Kota Binjai tahun 2011-2030, Kecamatan Binjai Utara ditetapkan sebagai lokasi kawasan industri. Industri yang direncanakan akan dikembangkan adalah industri teknologi tinggi. Namun masalahnya apakah jenis industri yang ditetapkan di RTRW ini adalah industri yang sesuai dengan potensi dan sumber daya lokal Kecamatan Binjai Utara? Tujuan paper ini untuk menemukan industri yang tepat untuk dikembangkan sesuai dengan potensi lokal atau keunggulan Kota Binjai khususnya di Kecamatan Binjai Utara. Alat analisis yang digunakan adalah analisis LQ, shift share dan SWOT untuk ditemukan potensi dan keunggulan Kota Binjai sehingga dapat dilihat kesesuaiannya dengan industri yang diarahkan oleh RTRW. Analisis menunjukkan bahwa sektor industri sebenarnya bukan merupakan sektor andalan atau potensi Kota Binjai. Hasil perhitungan LQ dan shift share menunjukkan bahwa sektor yang potensial untuk dikembangkan di Kota Binjai adalah sektor konstruksi, keuangan dan jasa-jasa. Kesamaan dengan kebijakan RTRW hanya pada sektor jasa. Hal ini menunjukkan bahwa sektor jasa dapat dikembangkan sedangkan industri komputer, multimedia, penerbitan dan percetakan tidak sesuai dengan potensi lokal. Namun, apabila tetap ingin mengembangkan sektor industri di Binjai Utara, maka perlu dilakukan strategi diversifikasi, yaitu membangun industri yang berhubungan dengan sektor unggulannya antara lain industri bahan bangunan dan industri tambang.
\end{abstract}

Kata Kunci: strategi pengembangan industri, analisis LQ dan Shift Share, SWOT

\begin{abstract}
Manufacturing industry is a leading sector that has potentials for promoting rapid growth in a region. The growth that relies on the industrial sector is driven by the sales of production, employment, and other multiplier effects so that many districts or cities in North Sumatra are eager to developing this sector. The types of industry that can be developed are supposed to be appropriate to the industry potentials and local resources in order to boost an optimal growth in the region. In the spatial planning (RTRW) of Binjai City 2011 - 2030, the
\end{abstract}

\footnotetext{
${ }^{1}$ Korespondensi Penulis: Institut Teknologi Medan, Medan, Indonesia Email: eresina22@yahoo.com
} 
North Binjai District designated as an industrial area. The type of industry which is planned to be developed is a high-tech industry. However, the problem is whether the type specified in the RTRW is suitable to the potentials of local resources? This paper aims to find out the suitable industry to be developed in compliance with the local potentials, especially in the North Binjai District. The analyses applied are LQ, shift share and SWOT to discover the potentials and advantages of the city in comparison to those industries endorsed in the $R T R W$. The results show that the industrial sector is neither the leading nor potential sector in Binjai. Meanwhile, the results of $L Q$ and shift share analyses show that the sector with the potentials to be developed in Binjai is the construction sector, finance, and services. The similarity to the RTRW policy is only in the service sector. It shows that the service sector can be developed while the computer industry, multimedia, publishing, and printing mismatch the local potentials. However, if the government still wants to develop the industrial sector in North Binjai, there should be diversification strategies to promoting the leading sectors such as building materials and mining industries.

Keywords: industrial development strategy, LQ and Shift Share analysis, SWOT analysis

\section{Pendahuluan}

Sektor industri merupakan salah satu sektor yang berpotensi menciptakan pertumbuhan progresif di sebuah kawasan. Sektor ini layak dikembangkan menjadi tulang punggung perekonomian. Hal inilah yang mendorong Kota Binjai untuk merencanakan pembangunan kawasan industri di Kota Binjai. Keberadaan sektor industri diharapkan dapat menjadi mesin penggerak (engine of growth) perekonomian Kota Binjai.

Implementasi awal dalam pengembangan sektor industri di Kota Binjai adalah dengan ditetapkannya wilayah kawasan industri di sekitar Kecamatan Binjai Utara pada Rencana Tata Ruang dan Wilayah (RTRW) Kota Binjai Tahun 2011 - 2030. Berdasarkan hasil kajian RTRW Kota Binjai tahun 2011 - 2030, kebijakan pengembangan industri di Kota Binjai adalah sebagai berikut:

1. Industri padat karya industri high tech yang meliputi industri komputer, multimedia, penerbitan dan percetakan, perusahaan jasa lainnya yang menggunakan teknologi menengah dan tinggi, dan pergudangan terpadu dialokasikan di Binjai Utara.

2. Industri yang tidak berwawasan lingkungan dan menimbulkan dampak terhadap lalu lintas dan jaringan jalan harus keluar dari Kota Binjai secara bertahap.

3. Lokasi industri tidak berwawasan lingkungan diarahkan untuk menjadi industri berwawasan lingkungan atau dialih fungsikan menjadi kegiatan jasa.

Pengembangan industri di Kota Binjai telah didukung oleh kesediaan masyarakat lokal untuk dikembangkan kawasannya sebagai kawasan industri serta peluang penyediaan infrastruktur jalan baru kedepannya. Namun, tingkat pendidikan masyarakat yang rendah serta ancaman spekulasi lahan oleh para pemilik modal karena banyak lahan yang belum dimiliki pemerintah menjadi hambatan tersendiri. Padahal, upaya untuk mengembangkan perekonomial lokal melalui optimalisasi potensi lokal agar menghasilkan multilier effect bagi masyarakat lokal perlu diperhatikan.

Dari latar belakang tersebut lalu muncul pertanyaan apakah kebijakan RTRW mengenai penetapan jenis industri (komputer, multimedia, penerbitan, percetakan) perusahaan jasa, pergudangan terpadu telah sesuai dengan potensi atau keunggulan daerah Kota Binjai? Adapun tujuan dari paper ini adalah untuk menemukan jenis industri yang tepat untuk dikembangkan sesuai dengan potensi lokal atau keunggulan Kota Binjai. Terkait dengan hal tersebut, maka perlu terlebih dahulu dilakukan analisis sektor unggulan Kota Binjai untuk mendukung pembangunan kawasan industri di Kota Binjai. Melalui 
analisis sektor unggulan ini akan dapat dilihat mengenai kesesuaian arahan industri yang ditetapkan dalam RTRW dengan kondisi ekonomi lokal Kota Binjai.

\section{Teori Pembangunan Wilayah Berdasarkan Sektor Unggulan}

Suatu sektor dikatakan unggul apabila sektor tersebut mampu bersaing dengan sektor yang sama di daerah lain atau di negara lain (Widodo, 2006). Penentuan sektor unggulan penting dilakukan untuk mengetahui sektor apa yang mampu mendatangkan pendapatan bagi daerah dengan cara ekspor atau menjual ke daerah lain secara efektif dan efisien. Efisiensi dan efektivitas dapat dicapai, salah satunya dengan mengandalkan sumber daya, bahan baku dan tenaga kerja lokal. Hanya komoditas yang dihasilkan secara efisien yang mampu bersaing sehingga penetapan sektor ekonomi unggulan atau komoditas unggulan penting bagi tiap daerah.

Ekonomi lokal suatu wilayah berperan penting dalam meningkatkan kesejahteraan penduduk lokal. Untuk itu, perlu untuk mengetahui kondisi kekuatan, kelemahan dan perubahan yang terjadi dalam perekonomian lokal suatu wilayah (Klosterman, 1990). Pertumbuhan ekonomi wilayah dapat ditingkatkan melalui sektor ekonomi unggulan yang memiliki potensi daya saing komparatif karena memiliki efek pengganda yang besar (Amalia, 2012; Titisari, 2011). Diversifikasi sektor ekonomi menunjukkan bahwa ada ketergantungan spesialisasi ekonomi antar wilayah yang dapat meningkatkan kondisi perekonomial lokal (Fattah \& Rahman, 2013).

Diperlukan peran pemerintah lokal, komunitas, dan pihak swasta dalam memanajemen sumber daya lokal yang dimiliki. Selain akan menciptakan lapangan pekerjaan baru, langkah tersebut juga akan menggenerator perkembangan aktivitas ekonomi wilayah tersebut (Arsyad, 2005). Ketersediaan sumber daya lokal, fasilitas dan infrastruktur pendukung, jumlah dan kapasitas penduduk dalam mengolah sumber daya lokal yang dimiliki berperan dalam pertumbuhan ekonomi suatu wilayah (Adisasmita, 2009).

Dengan bergeraknya sektor unggulan, maka investasi dan permintaan tenaga kerja semakin bertambah. Hal ini dapat meningkatkan permintaan atau menggerakkan sektorsektor non unggulan. Dengan dasar pemikiran ini, maka menemukan sektor unggulan suatu daerah merupakan langkah penting dalam menentukan prioritas pembangunan atau rencana pembangunan suatu daerah. Sektor unggulan dipastikan memiliki potensi besar untuk tumbuh cepat dibandingkan sektor lainnya karena adanya faktor pendukung terhadap sektor tersebut, seperti bahan baku, tenaga kerja dan lainnya.

Contoh best practice adalah di Kota Batu, Malang. Kecamatan-kecamatan di Kota Batu umumnya berbasis di sektor pertanian. Melihat hal ini, maka sejak tahun 1993, kota ini dicanangkan mengembangkan agrowisata. Jumlah produksi buah apel yang besar menjadikan apel sebagai komoditi unggulan di beberapa kecamatan di kota ini. Dorongan pengembangan kepada komoditas unggulan di kota ini adalah dengan menghasilkan makanan yang berbahan dasar apel dan sejak tahun 2005 dikembangkan wisata petik apel. Wisata petik apel di Kota Malang sangat berkembang hingga kini. Banyak turis asing yang berkunjung ke kota ini untuk menikmati kegiatan petik buah apel. Pada tahun 2013, ada sekitar 60 ribu pengunjung yang menikmati wisata petik buah apel di Kota Batu. Kunjungan wisata secara umum juga meningkat. Pada tahun 2011, jumlah wisatawan sebanyak 2,5 juta orang, tahun 2012 naik menjadi 4 juta orang, dan tahun 2013 naik menjadi 5 juta. Kegiatan ini juga sangat memberi keuntungan bagi petani apel di sana (Utomo, 2011). Dari contoh best practice ini dapat disimpulkan bahwa bila suatu daerah mengembangkan sektor unggulannya, maka daerah tersebut akan maju. 


\section{Metode Analisis}

Analisis dilakukan untuk menemukan sektor unggulan di Kota Binjai. Pengumpulan data dilakukan dengan metode survei melalui metode pengumpulan data primer yang diperoleh secara langsung dengan metoda wawancara dan data sekunder yang didapat dari nilai-nilai PDRB Kota Binjai tahun 2008 - 2011. Wawancara dilakukan dengan instansi terkait, seperti Pihak Kelurahan, Dinas Lingkungan, Dinas Pertanian, dan lainnya. Data diambil dari instansi Pusat Pelayanan Satu Atap dan lainnya.

Teknik analisis data yang digunakan dalam penelitian ini adalah dengan analisis LQ, Shift Share dan SWOT. Justifikasi pemilihan ketiga alat analisis tersebut adalah karena sebelum menentukan jenis industri yang tepat untuk dikembangkan di Kota Binjai, perlu terlebih dahulu mengetahui sektor ekonomi unggulan yang potensial untuk dikembangkan melalui analisis LQ dan Shift Share. Selanjutnya, dalam menentukan jenis industri yang patut dikembangkan digunakan analisis SWOT dengan mempertimbangkan kekuatan, kelemahan, kesempatan dan ancaman yang akan dihadapi. Masing-masing alat analisis terjabarkan sebagai berikut:

1) Analisis LQ

Analisis LQ digunakan untuk menentukan sektor ekonomi basis (ekspor) dan non basis Kota Binjai. Di dalam analisis ini ekonomi diasumsikan tertutup dan asumsi lainnya yaitu jika suatu daerah lebih berspesialisasi dibanding negara dalam menghasilkan produk tertentu LQ $>1$, maka daerah tersebut akan mengeskspor barang tersebut (Widodo, 2006). Serupa dengan Klosterman (1990) yang mengungkapkan bahwa teknik analisis LQ adalah alat analisis termudah dalam analisis ekonomi regional yang membagi ekonomi lokal dalam 2 sektor, yaitu sektor basis (bukan sektor lokal) dan non basis (sektor lokal) Dalam studi ini, analisis LQ digunakan untuk menemukan sektor ekonomi basis Kota Binjai.

2) Analisis Shift Share

Analisis shift share adalah suatu teknik kuantitatif yang digunakan untuk mengetahui perkembangan atau pertumbuhan sektor ekonomi suatu daerah relatif terhadap daerah referensinya. Dengan analisis ini, diharapkan dapat diketahui mengenai sektor ekonomi yang potensial berpotensi untuk dikembangkan di Kota Binjai.

3) Analisis SWOT

Yang dimaksud dengan analisis SWOT adalah suatu teknik menganalisis faktor-faktor internal dan eksternal menjadi langkah-langkah strategi dalam pengoptimalan lagkah. Dalam analisis faktor-faktor internal dan eksternal, akan ditentukan aspek-aspek yang menjadi kekuatan (Strengths), kelemahan (Weakness), kesempatan (Opportunities) dan yang menjadi ancaman (Threat) bagi sebuah rencana pembangunan. Dengan begitu akan dapat ditentukan berbagai kemungkinan alternatif strategi yang dapat dijalankan (Rangkuti, 2005).

\section{Gambaran Umum Perekonomian Kota Binjai}

Pada kondisi saat ini, guna lahan di Binjai Utara umumnya adalah pertanian dan perkebunan. Penggunaan lahan sebagai pertanian memiliki proporsi terbesar di Kecamatan Binjai Utara. Lahan pertanian lain juga terdapat di Binjai Selatan dan Binjai Timur. Peta guna lahan di Kota Binjai terlihat di Gambar 1. Jenis tanah di Kota Binjai secara umum adalah tanah andosol coklat dan tanah humus regosol yang subur sehingga cocok untuk aktivitas pertanian. Kecamatan Binjai Utara merupakan penghasil tanaman pangan terbesar. Ini dikarenakan Kecamatan Binjai Utara memiliki lahan sawah terluas mencapai 825,16 ha sawah tadah hujan. Hal ini akhirnya berdampak pada produksi padi yang dihasilkan. Produksi padi di Kecamatan Binjai Utara menjadi produksi yang terbesar di Kota Binjai. Pada tahun 2012, produksi padi di Binjai Utara mencapai 12.111 ton. Selain 
padi, Kecamatan Binjai Utara juga menjadi penghasil jagung, kacang tanah, kacang hijau, kacang panjang dan cabai terbesar yang terbesar produksinya di Kota Binjai.

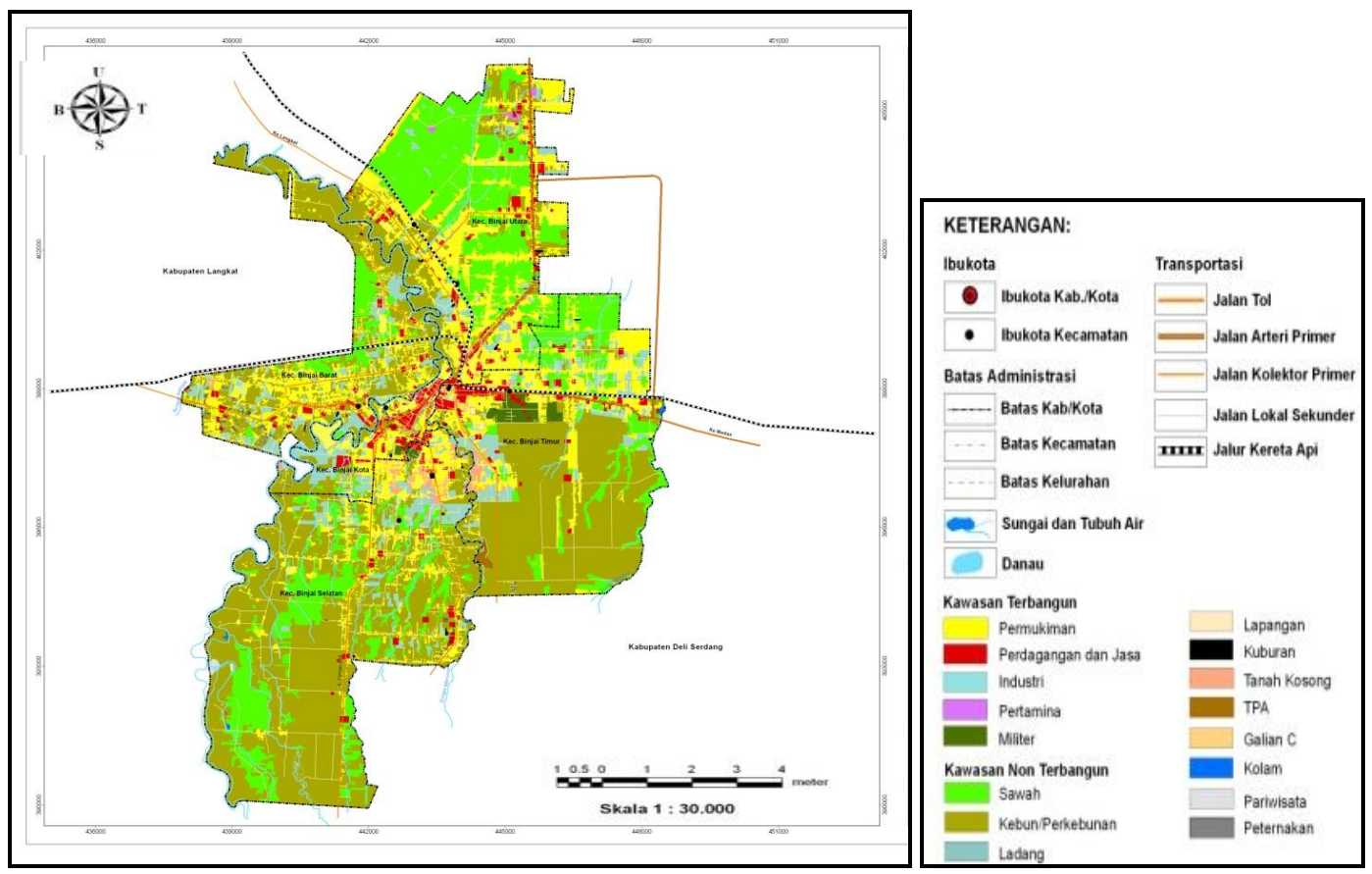

Sumber: RTRW Kota Binjai, 2011-2030

\section{Gambar 1. Peta Guna Lahan Kota Binjai}

\section{Ketenagakerjaan}

Jumlah penduduk Kota Binjai pada pertengahan tahun 2014 sebanyak 261.490 jiwa. Persentase penduduk berdasarkan diagram ketenagakerjaan terdiri dari 2 kelompok yaitu: kelompok penduduk berusia kerja ( 15 - 65 tahun) dan bukan berusia kerja (kurang dari 15 tahun dan lebih dari 65 tahun) yang proporsinya terlihat di Gambar 2.

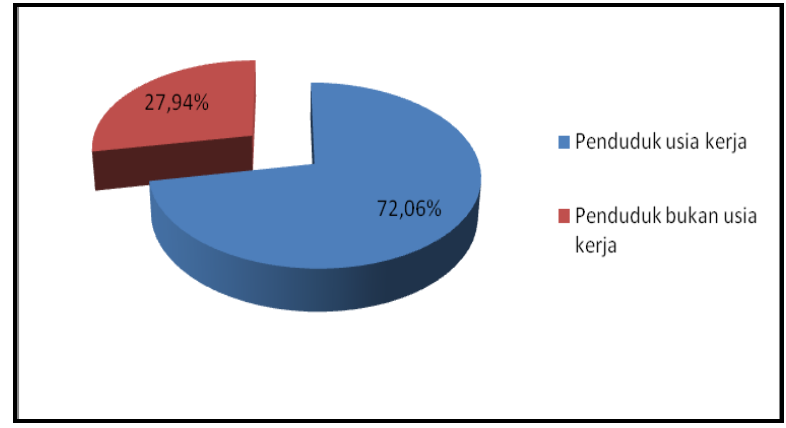

Sumber: Indikator Ketenagakerjaan Kota Binjai, 2014

Gambar 2. Persentase Penduduk berdasarkan Kondisi Ketenagakerjaan Tahun 2014 
Dilihat dari lapangan pekerjaan utama, umumnya penduduk berumur 15 tahun ke atas bekerja di sektor perdagangan dan jasa kemasyarakatan. Walaupun merupakan sektor khusus, aktivitas perdagangan masuk ke dalam aktivitas jasa. Lebih jelasnya dapat dilihat pada Tabel 1.

Tabel 1. Penduduk Berusia Lebih dari 15 Tahun yang Bekerja Seminggu Lalu Menurut Lapangan Pekerjaan Utama di Kota Binjai Tahun 2014

\begin{tabular}{|c|c|c|c|c|}
\hline \multirow{2}{*}{ No } & \multirow{2}{*}{ Lapangan Pekerjaan Utama } & \multicolumn{2}{|c|}{ Jenis Kelamin (Jiwa) } & \multirow{2}{*}{$\begin{array}{c}\text { Jumlah } \\
\text { (Jiwa) }\end{array}$} \\
\hline & & Laki-laki & Perempuan & \\
\hline 1 & Pertanian, perkebunan, perburuan dan perikanan & 4.800 & 914 & 5.714 \\
\hline 2 & Pertambangan dan penggalian & 508 & 0 & 508 \\
\hline 3 & Industri Pengolahan & 6.209 & 3.752 & 9.961 \\
\hline 4 & Listrik, gas dan air minum & 602 & 0 & 602 \\
\hline 5 & Konstruksi & 15.494 & 323 & 15.817 \\
\hline 6 & Perdagangan,rumah makan dan jasa akomodasi & 18.579 & 17.396 & 35.975 \\
\hline 7 & Transportasi,pergudangan dan komunikasi & 9.959 & 528 & 10.487 \\
\hline 8 & $\begin{array}{l}\text { Lembaga keuangan, real estate, usaha persewaan } \\
\text { dan jasa perusahaan }\end{array}$ & 3.402 & 798 & 4200 \\
\hline \multirow[t]{2}{*}{9} & Jasa kemasyarakatan, sosial dan perorangan & 12.720 & 15.188 & 27.908 \\
\hline & Total Kota Binjai & 72.273 & 38.899 & 111.172 \\
\hline
\end{tabular}

Sumber: Indikator Ketenagakerjaan Kota Binjai, 2014

Angkatan kerja di Kota Binjai umumnya adalah lulusan SMA dan lulusan SD dan SMP. Lebih jelasnya dapat dilihat pada Tabel 2 .

Tabel 2. Penduduk Berusia Lebih dari 15 Tahun yang Termasuk Angkatan Kerja Menurut Pendidikan Tertinggi yang Ditamatkan di Kota Binjai 2014

\begin{tabular}{llccc}
\hline \multirow{2}{*}{ No } & \multirow{2}{*}{ Pendidikan Tertinggi yang Ditamatkan } & \multicolumn{2}{c}{ Jenis Kelamin (Jiwa) } & Jumlah \\
\cline { 3 - 4 } & Tidak/ belum pernah sekolah/ tidak/ belum tamat & Laki-laki & Perempuan & (Jiwa) \\
\cline { 3 - 4 } 1 & SD/ SD & 13.881 & 11.783 & 25.664 \\
2 & SMP & 17.888 & 7.735 & 25.623 \\
3 & SMA & 23.741 & 10.650 & 34.391 \\
4 & SMK & 15.959 & 4.345 & 20.304 \\
5 & Diploma I/II/III & 494 & 1.629 & 2.123 \\
6 & Akademi/universitas & 6.228 & 5.978 & $12 . .206$ \\
& Total Kota Binjai & $\mathbf{7 8 . 1 9 1}$ & $\mathbf{4 2 . 1 2 0}$ & $\mathbf{1 2 0 . 3 1 1}$ \\
\hline
\end{tabular}

Sumber: Indikator Ketenagakerjaan Kota Binjai, 2014

Sama seperti pada sektor formal, penduduk usia kerja umumnya bekerja pada sektor informal juga lebih banyak bergerak di bidang jasa. Hal ini menunjukkan bahwa sektor jasa sudah sedemikian banyak menyerap tenaga kerja di Kota Binjai. Lebih jelasnya dapat dilihat pada Gambar 3. 


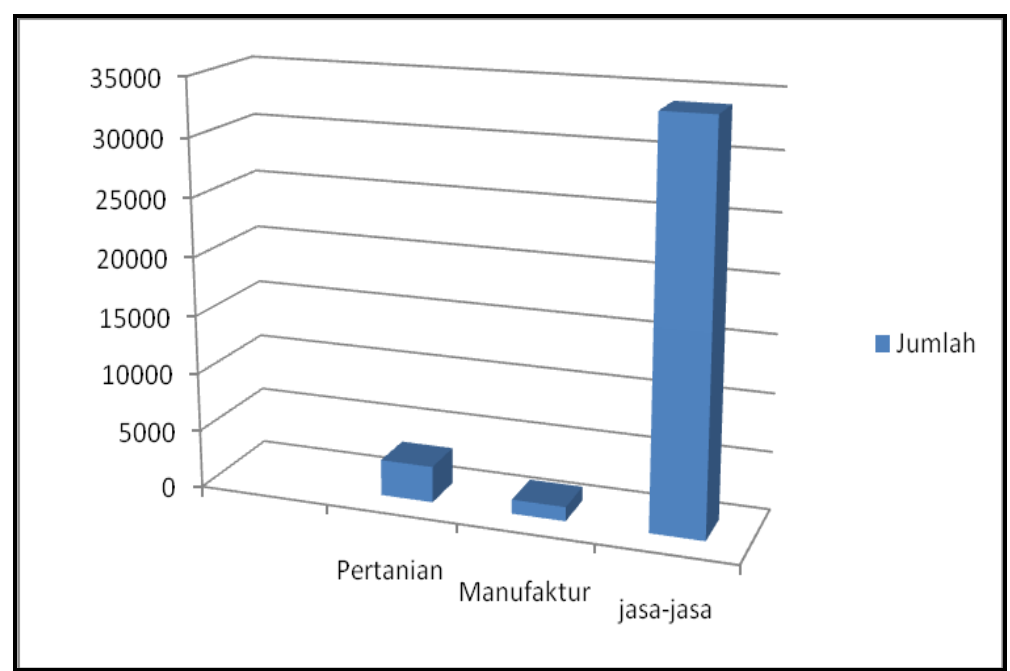

Sumber: Indikator Ketenagakerjaan Kota Binjai, 2014

\section{Gambar 3. Penduduk Berusia Lebih Dari 15 Tahun yang Bekerja Selama Seminggu Yang Lalu di Kegiatan Informal Menurut Lapangan Pekerjaan Utama di Kota Binjai, 2014}

\section{Potensi Perindustrian Kota Binjai}

Pada tahun 2011, terdapat 9 perusahaan industri dengan 122 tenaga kerja dan nilai investasi sebesar Rp 811.000.000 di Kota Binjai. Dari data jumlah penerbitan tanda daftar perusahaan di Kota Binjai, ada sebanyak 23 badan usaha berbentuk PT, 4 badan usaha berbentuk Koperasi, 67 badan usaha berbentuk CV, serta 111 badan usaha berbentuk PO. Tanda daftar perusahaan terbanyak berada di Binjai Kota sebanyak 62, kemudian Binjai Utara sebanyak 41 buah. Gambar 4 menunjukkan jumlah penerbitan tanda daftar perusahaan di Kota Binjai.

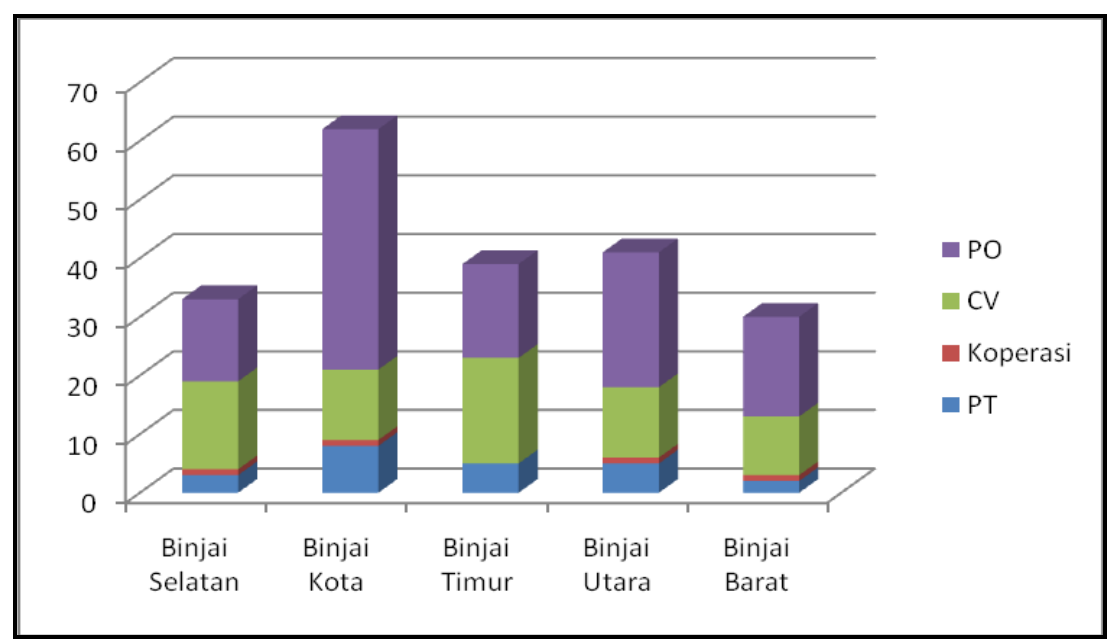

Sumber: Binjai dalam Angka, 2012

Gambar 4. Jumlah Penerbitan Tanda Daftar Perusahaan di Kota Binjai Tahun 2011 


\section{Menemukan Strategi Pengembangan Kawasan Industri Melalui Analisis Sektor Unggulan Kota Binjai}

Jumlah penerbitan tanda daftar perusahaan terbanyak adalah di sektor perdagangan sebanyak 110 buah. Gambar 5 menunjukkan jumlah penerbitan tanda daftar perusahaan di Kota Binjai Tahun 2011.

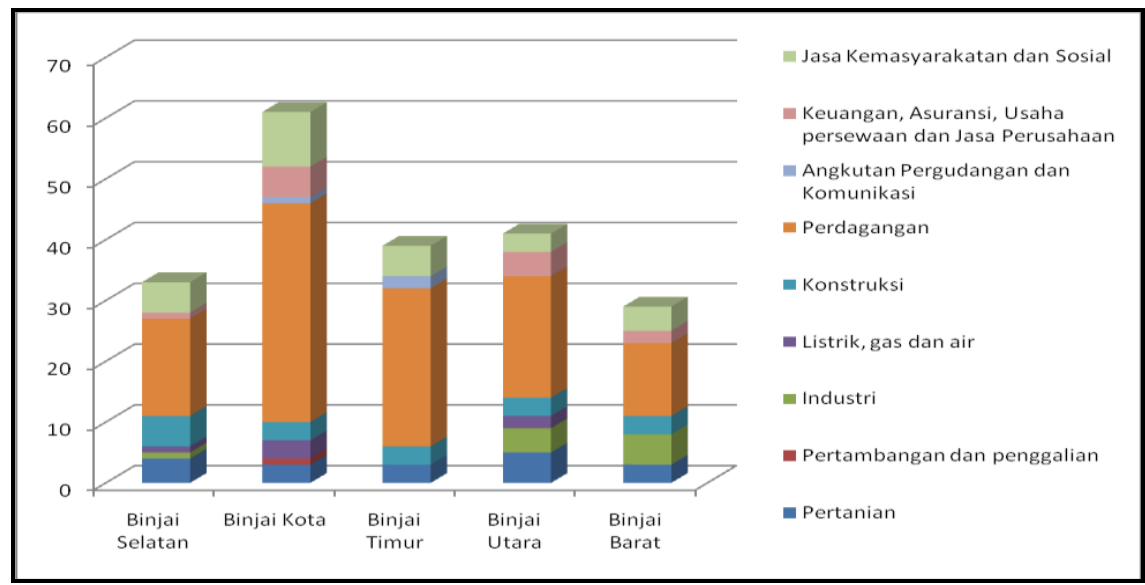

Sumber: Binjai dalam Angka, 2012

\section{Gambar 5. Jumlah Penerbitan Tanda Daftar per Perusahaan di Kota Binjai Tahun 2011}

Kota Binjai memiliki jumlah industri yang banyak terutama untuk industri rumah tangga. Namun demikian, trennya menunjukkan tren penurunan yang tajam antara tahun 2013 hingga 2014. Jika dilihat dari jenis industrinya, jenis industri yang terbanyak di Kota Binjai adalah industri makanan dan minuman dengan jumlah perusahaan sebanyak 7 perusahaan dan tenaga kerja sebanyak 98 orang. Selain itu ada industri barang-barang dari logam, mesin dan perlengkapannya serta industri pengolahan lainnya dengan jumlah masing-masing 1 perusahaan. Jumlah industri pada tahun 2012 dan 2013 tidak banyak berubah. Namun jumlah industri mengalami penurunan pada tahun 2014. Penurunan terbesar terjadi pada jumlah industri rumah tangga. Lebih jelasnya dapat dilihat pada Gambar 6.

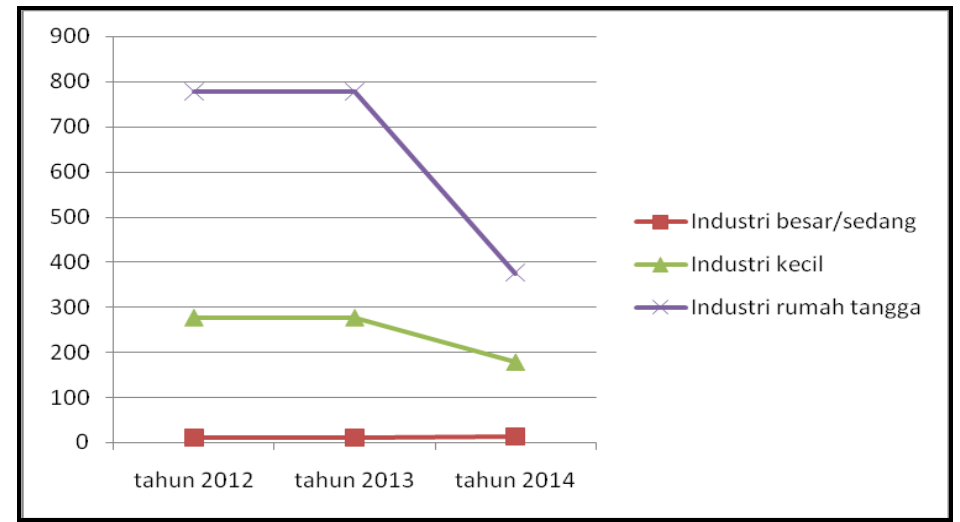

Sumber: Statistik Daerah Binjai, 2015

Gambar 6. Jumlah industri di Kota Binjai Tahun 2012-2014 


\section{Infrastrukturyang Mendukung Industri}

Aktivitas industri di Kota Binjai telah didukung beberapa infrastruktur pendukung meliputi:

1. Adanya jalan nasional yang menghubungkan Aceh, Binjai dan Medan

2. Adanya kereta api yang menghubungkan Aceh, Binjai dan Medan

3. Sedang dibangunnya tol dari Binjai ke Medan sehingga pergerakan barang dan orang dari Aceh ke Binjai atau ke Medan semakin cepat.

4. Adanya terminal tipe $\mathrm{C}$

5. Adanya TPA

Lokasi infrastruktur pendukung aktivitas industri di Kota Binjai terlihat di Gambar 7.

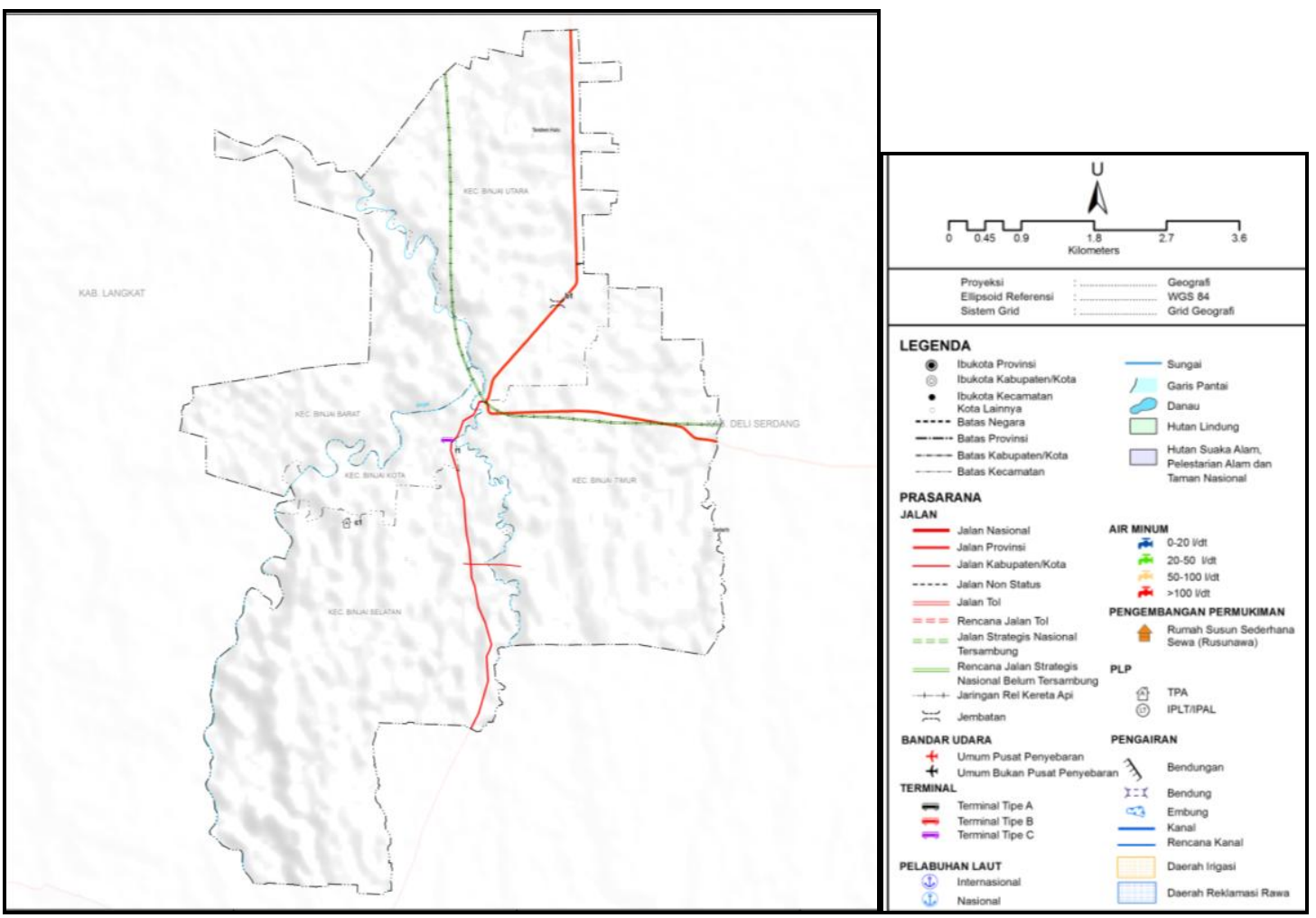

Sumber: RTRW Kota Binjai, 2011-2030

\section{Gambar 7. Dukungan Kondisi Infrastruktur di Kota Binjai}

\section{Kedudukan Kota Binjai dalam Rencana Tata Ruang Nasional dan Rencana Tata Ruang Provinsi}

Berdasarkan Peraturan Pemerintah No. 26 Tahun 2008 tentang Rencana Tata Ruang Wilayah Nasional (RTRWN) dijelaskan bahwa Kota Binjai termasuk dalam Kawasan Metropolitan MEBIDANGRO (Medan-Binjai-Deli Serdang-Tanah Karo), dimana sektor unggulannya adalah sektor-sektor industri, perkebunan, pariwisata, pertanian dan perikanan.

Berdasarkan RTRW Propinsi (Perda Propinsi Sumatera Utara No 7 Tahun 2003), pusat-pusat pertumbuhan Mebidang adalah:

- $\quad$ Kota Binjai dan Lubuk Pakam sebagai Major Growth Centers

- $\quad$ Tanjung Morawa dan Pancur Batu sebagai Minor Growth Centers. 


\section{Menemukan Strategi Pengembangan Kawasan Industri Melalui Analisis Sektor Unggulan Kota Binjai}

Pada Mebidang, juga sudah ditetapkan bahwa Kota Binjai sebagai kota satelit dari Kota Medan dengan fungsi utama sebagai pusat perdagangan dan jasa, pusat kawasan industri, pusat agrobisnis dan pusat permukiman. Lebih jelasnya dapat dilihat pada Gambar 8.

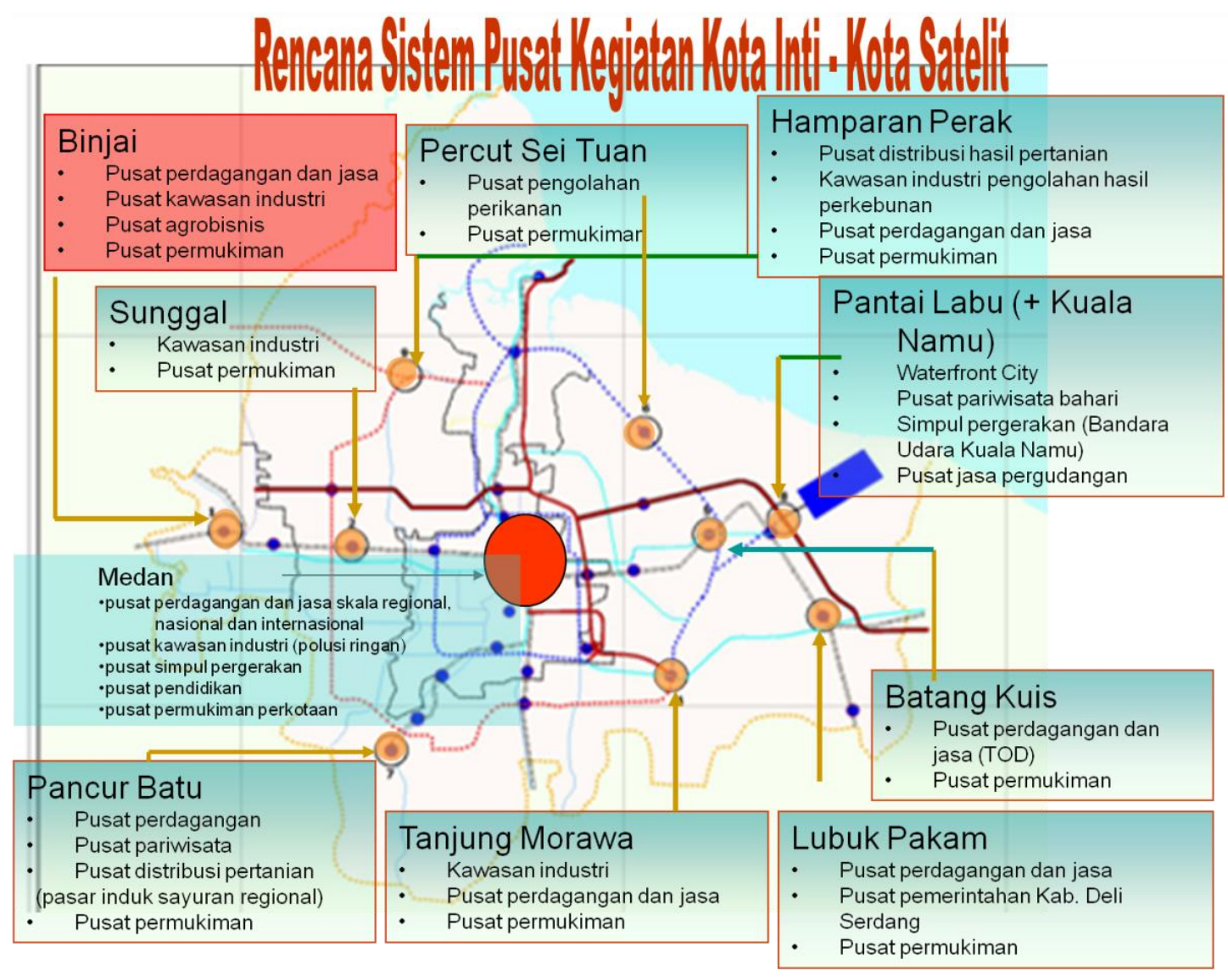

Sumber: RTRW Kota Binjai, 2011-2030

\section{Gambar 8. Rencana Sistem Pusat Kegiatan Kota Inti-Kota Satelit}

\section{Binjai Utara Sebagai Kawasan Strategis Kota Binjai}

Kawasan budidaya strategis di Kota Binjai yang perlu segera didorong perkembangannya meliputi:

a. Kawasan Industri di Kecamatan Binjai Utara tepatnya di Kelurahan Cengkeh Turi dan Jati Mulyo.

b. Kawasan perdagangan dan jasa di pusat kota, pusat BWK dan di koridor jalan-jalan utama kota.

Pengembangan kawasan industri dan pergudangan ini merupakan pengakomodasian terhadap pengembangan Metropolitan Mebidangro, dan sekaligus upaya untuk mengarahkan perkembangan industri Kota Binjai yang lebih tertata sejak dini. Kawasan industri dan pegudangan ini dikembangkan sebagai Kawasan Industri yang diarahkan terutama untuk industri non polutif. Kawasan pusat kota yang direncanakan ini terletak pada kawasan / lingkungan yang relatif telah terbangun, yang terdiri atas:

- Kegiatan yang baru dikembangkan (seperti pertokoan, bank, kantor, dsb.), yang bangunannya relatif baru; 
- Kegiatan yang merupakan lanjutan sebelumnya (seperti toko, fasilitas pendidikan, perumahan, dan lainnya) yang bangunannya relatif masih terpelihara;

- Kegiatan yang telah menurun fungsi pelayanannya (eks toko-toko lama, eks perumahan lama) dengan bangunan yang menurun kondisi atau penampilannya.

Kegiatan perdagangan koridor adalah kegiatan perdagangan dan jasa, selaras dengan kecenderungan atau trend yang ada dewasa ini, khususnya di sepanjang jalan Amir Hamzah dan jalan menuju Medan. Kendati demikian pada koridor ini masih terdapat juga kegiatan yang bukan merupakan kegiatan perdagangan dan jasa, seperti perkantoran, fasilitas sosial (rumah sakit), dan hunian.

Kawasan strategis lainnya adalah rencana pusat pemerintahan di Kota Binjai yang diarahkan di Kawasan eks HGU Kebun Tebu PTPN II yaitu di sekitar Kecamatan Binjai Timur Kelurahan Tenggu Rono meliputi area seluas 90,52 Ha. Selain itu, kawasan strategis lainnya adalah kawasan strategis yang berkaitan dengan lingkungan yaitu:

a. Kawasan Pariwisata Alam Pantai SB.

b. Kawasan Rencana pengembangan Bottanical Garden/ hutan kota di sekitar kawasan pusat pemerintahan dan di Kawasan Wisata pantai SB.

c. Kawasan rencana pengembangan waduk-waduk buatan yang menyebar di Kota Binjai.

Seluruh kawasan strategis tersebut dapat dilihat pada Gambar 9. Dari rencana kawasan strategis tersebut, terlihat bahwa pembangunan kawasan industri di Kota Binjai sesuai RTRW Kota Binjai 2011-2030 di lokasikan di Kelurahan Cengkeh Turi, Kecamatan Binjai Utara.

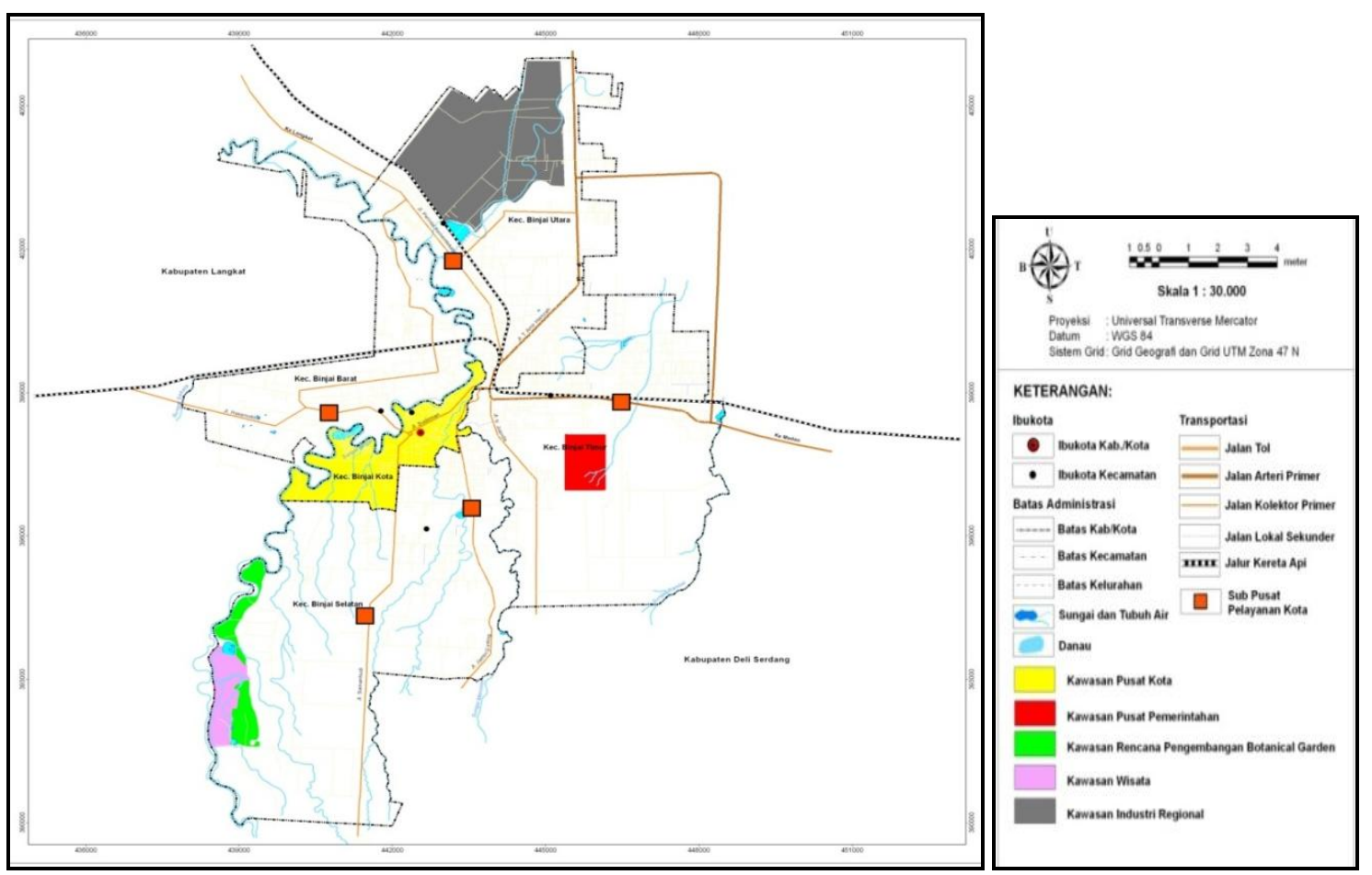

Sumber: RTRW Kota Binjai, 2011-2030

Gambar 9. Rencana Kawasan Strategis Kota Binjai 


\section{Potensi Industri di Kecamatan Binjai Utara}

Kawasan ini sudah lama ditetapkan sebagai kawasan industri. Sedikit demi sedikit industri berkembang di kecamatan ini. Industri tersebut antara lain adalah industri logam dasar dari besi dan baja, industri pembuatan makanan ringan, industri pembuatan kusen pintu dan jendela, penggilingan jagung, dll. Lebih jelasnya dapat dilihat pada Tabel 3.

Tabel 3. Daftar Nama Perusahaan di Kecamatan Binjai Utara Tahun 2011-2013

\begin{tabular}{|c|c|}
\hline NAMA USAHA & JENIS USAHA \\
\hline NILLA SARI, UD & Pembuatan roti kering dan makanan ringan \\
\hline PRIMA INDAH SANITON, PT & $\begin{array}{l}\text { Pembuatan kloset, wastafel dan tempat } \\
\text { sabun porselin }\end{array}$ \\
\hline BINTANG CENDRAWASIH/SELAMAT & Pembuatan makanan ringan \\
\hline ALAM JAYA/SUDARMAN & Pembuatan kusen \\
\hline PAK TUNG TUNG/AHO/GUNAWAN & Pembuatan bon-bon \\
\hline LAPIGA MAKMUR JAYA, PT & Pengolahan bahan baku kayu masyarakat \\
\hline GAHARU PUTRA BAJA MANDIRI, PT & Pembuatan tiang listrik besi baja \\
\hline KARYA AGRO LESTARI, CV & Pengolahan minyak kelapa sawit \\
\hline YUDIKA-DN, UD & Pembuatan makanan ringan \\
\hline PUTRA DAMAI & Kilang padi \\
\hline IQBAL & Pembuatan kusen pintu dan jendela \\
\hline ALAM JAYA, UD & $\begin{array}{l}\text { Pembuatan kusen pintu jendela, pintu dan } \\
\text { perabot rumah tangga }\end{array}$ \\
\hline DUA PUTRA & Pembuatan makanan ringan \\
\hline ALAM JAYA BARU, UD & $\begin{array}{l}\text { Pembuatan kusen pintu, jendela, perabot } \\
\text { rumah tangga dan bahan bangunan }\end{array}$ \\
\hline GAHARU PUTRA BAJA MANDIRI, PT & Industri logam dasar dari besi dan baja \\
\hline SAHABAT MAJU & Penggilingan jagung \\
\hline MAHKOTA FOOD (MF), UD & $\begin{array}{l}\text { Industri air mineral dan minuman ringan } \\
\text { sirup }\end{array}$ \\
\hline AMANDA & Pembuatan peti mati \\
\hline SERASI & Pembuatan makanan ringan \\
\hline
\end{tabular}

Sumber: Pusat Pelayanan Satu Atap, 2013

Berdasarkan catatan Badan Pengendalian Dampak Lingkungan Kota Binjai, terdapat 17 perusahaan dan perdagangan di Binjai Utara yang sudah lulus ijin SPPL (Surat Pernyataan Kesanggupan Pengelolaan dan Pemantauan Lingkungan Hidup). Perusahaan tersebut termasuk pengembang perumahan, rumah sakit, pergudangan, dan usaha dagang berupa ruko.

\section{Analisis}

\section{Analisis LQ (Location Quotient) PDRB Kota Binjai}

Analisis LQ digunakan untuk melihat sektor-sektor di Kota Binjai yang memiliki peran wilayah yang besar serta prospektif untuk dikembangkan. Penghitungan LQ ini menggunakan data PDRB yang terdiri dari sembilan sektor/lapangan usaha berdasarkan Harga Konstan yang dibandingkan dengan data PDRB Provinsi Sumatera Utara pada tahun 2010-2011. Tabel 4 menunjukkan hasil perhitungan LQ PDRB Kota Binjai. 
Tabel 4. Hasil Analisis LQ PDRB Kota Binjai Menurut Lapangan Usaha Tahun 2008-2011

\begin{tabular}{|c|c|c|c|c|c|c|}
\hline No & Lapangan Usaha & 2008 & 2009 & 2010 & 2011 & $\begin{array}{c}\text { Interpretasi } \\
\text { Berdasarkan } \\
\text { Hasil Tahun } \\
2011\end{array}$ \\
\hline 1 & $\begin{array}{l}\text { Pertanian, Peternakan, Kehutanan } \\
\text { Dan Perikanan / Agriculture, } \\
\text { Livestock, Forestry \& Fisherv }\end{array}$ & 0,030 & 0,303 & 0,299 & 0,297 & Sektor non basis \\
\hline 2 & $\begin{array}{l}\text { Pertambangan \& Penggalian/ Mining } \\
\& \text { Quarrying }\end{array}$ & 5,766 & 6,090 & 5,818 & 5,636 & Sektor basis \\
\hline 3 & $\begin{array}{l}\text { Industri Pengolahan/Manufacturing } \\
\text { Industry }\end{array}$ & 0,956 & 0,964 & 0,968 & 0,100 & Sektor non basis \\
\hline 4 & $\begin{array}{l}\text { Listrik, Gas \& Air Bersih/ Electrity, } \\
\text { Gas \& Water Supply }\end{array}$ & 2 & 2 & 2 & 0.189 & Sektor non basis \\
\hline 5 & Konstruksi/Construction & 1,287 & 1,313 & 1,358 & 1,376 & Sektor basis \\
\hline 6 & $\begin{array}{l}\text { Perdagangan, Hotel Dan Restoran/ } \\
\text { Trade, Hotel \& Restaurant }\end{array}$ & 0,928 & 0,902 & 0,885 & 0,850 & Sektor non basis \\
\hline 7 & $\begin{array}{l}\text { Pengangkutan \& } \\
\text { Komunikasi/Transport \& } \\
\text { Communication }\end{array}$ & 0,46 & 0,473 & 0,479 & 0,49 & Sektor non basis \\
\hline 8 & $\begin{array}{l}\text { Keuangan, Real Estat \& Jasa } \\
\text { Perusahaan/Finance, Real Estate }\end{array}$ & 2,328 & 2,281 & 1,964 & 2,012 & Sektor basis \\
\hline 9 & Jasa-Jasa/Services & 1,635 & 1,67 & 1,73 & 1,754 & Sektor basis \\
\hline
\end{tabular}

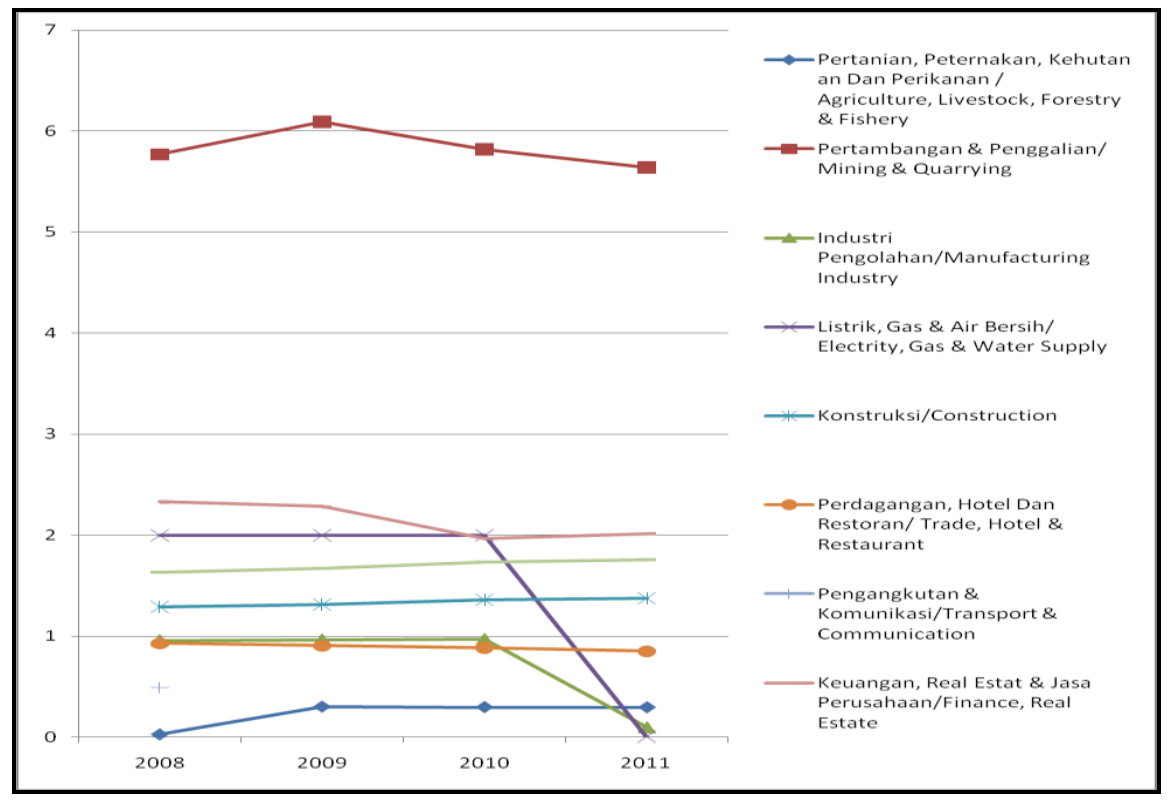

Gambar 10. Gambaran LQ Kota Binjai

Berdasarkan analisis LQ, dapat dilihat bahwa sektor di Kota Binjai yang merupakan sektor basis adalah sektor pertambangan dan penggalian, sektor konstruksi, sektor keuangan dan jasa. Pada tabel 10 dapat dilihat bahwa sektor industri adalah sektor non basis artinya selama ini sektor industri di Kota Binjai baru bisa memenuhi kebutuhan dalam wilayah Kota Binjai saja dan belum bisa diekspor. Begitu pula sektor pertanian yang juga merupakan sektor non basis. 


\section{Menemukan Strategi Pengembangan Kawasan Industri Melalui Analisis Sektor Unggulan Kota Binjai}

\section{Analisis Shift Share}

Untuk analisis shift share, digunakan data PDRB Kota Binjai Atas Dasar Harga Konstan 2000 Tahun 2008 dan 2011 dan PDRB Sumatera Utara Atas Dasar Harga Konstan 2000 Tahun 2008 dan 2011. Hasil analisis shift share yang dapat dilihat pada Tabel 5. Hasil analisis menunjukkan bahwa nilai keunggulan kompetitif yang bernilai positif di Kota Binjai adalah sektor listrik, konstruksi, pengangkutan dan jasa-jasa. Hal ini berarti sektor-sektor ini memiliki keunggulan komparatif atau siap bersaing dengan kabupaten/kota lain di Sumatera Utara. Bila dilihat dari pergeserannya, sektor yang bergerak progresif di Kota Binjai adalah sektor listrik, konstruksi; pengangkutan; keuangan dan jasa-jasa.

Tabel 5. Analisis Shift Share untuk Kota Binjai Tahun 2008 dan 2011

\begin{tabular}{|c|c|c|c|c|}
\hline \multirow[b]{2}{*}{ Lapangan Usaha } & \multicolumn{3}{|c|}{ Komponen } & \multirow[b]{2}{*}{ Interpretasi } \\
\hline & $\begin{array}{l}\text { Pertumbuhan } \\
\text { Sumatera } \\
\text { Utara (Nij) }\end{array}$ & $\begin{array}{l}\text { Bauran } \\
\text { Industri } \\
\text { (Mij) }\end{array}$ & $\begin{array}{l}\text { Keunggulan } \\
\text { Kompetitif } \\
\text { (Cij) }\end{array}$ & \\
\hline $\begin{array}{l}\text { Pertanian, Peternakan, } \\
\text { Kehutanan Dan Perikanan / } \\
\text { Agriculture, Livestock, } \\
\text { Forestry \& Fishery }\end{array}$ & 25.518 & -4.066 & -8.926 & $\begin{array}{l}\text { - Tidak memiliki } \\
\text { daya saing } \\
\text { - Tidak berkembang }\end{array}$ \\
\hline $\begin{array}{l}\text { Pertambangan \& Penggalian/ } \\
\text { Mining \& Quarrying }\end{array}$ & 23.843 & -5.462 & -15.864 & $\begin{array}{l}\text { - Tidak memiliki } \\
\text { daya saing } \\
\text { - Tidak berkembang }\end{array}$ \\
\hline $\begin{array}{l}\text { Industri } \\
\text { Pengolahan/Manufacturing } \\
\text { Industry }\end{array}$ & 74.781 & -38.442 & -17.286 & $\begin{array}{l}\text { - Tidak memiliki } \\
\text { daya saing } \\
\text { - Tidak berkembang }\end{array}$ \\
\hline $\begin{array}{l}\text { Listrik, Gas \& Air Bersih/ } \\
\text { Electrity, Gas \& Water Supply }\end{array}$ & 4.828 & 0.793 & 1.706 & $\begin{array}{l}\text { - Memiliki daya saing } \\
\text { - Berkembang }\end{array}$ \\
\hline Konstruksi/Construction & 29.160 & 6.855 & 21.759 & $\begin{array}{l}\text { - Memiliki daya saing } \\
\text { - Berkembang }\end{array}$ \\
\hline $\begin{array}{l}\text { Perdagangan, Hotel Dan } \\
\text { Restoran/ Trade, Hotel \& } \\
\text { Restaurant }\end{array}$ & 58.264 & 7.369 & -22.376 & $\begin{array}{l}\text { - Tidak Memiliki } \\
\text { daya saing } \\
\text { - Tidak Berkembang }\end{array}$ \\
\hline $\begin{array}{l}\text { Pengangkutan \& } \\
\text { Komunikasi/Transport \& } \\
\text { Communication }\end{array}$ & 14.847 & 8.209 & 13.412 & $\begin{array}{l}\text { - Memiliki daya saing } \\
\text { - Berkembang }\end{array}$ \\
\hline $\begin{array}{l}\text { Keuangan, Real Estat \& Jasa } \\
\text { Perusahaan/Finance, Real } \\
\text { Estate }\end{array}$ & 55.836 & 42.855 & -6.690 & $\begin{array}{l}\text { - Tidak Memiliki } \\
\text { daya saing } \\
\text { - Berkembang }\end{array}$ \\
\hline Jasa-Jasa/Services & 55.130 & 12.445 & 40.394 & $\begin{array}{l}\text { - Memiliki daya saing } \\
\text { - Berkembang }\end{array}$ \\
\hline JUMLAH & 342.206 & 30.555 & 6.130 & \\
\hline
\end{tabular}

Dari hasil analisis tersebut dapat dilihat bahwa sektor industri di Kota Binjai belum siap bersaing dengan sektor industri di kabupaten /kota lain di Sumatera Utara dan belum bergerak secara progresif. Sektor yang memiliki daya saing di Kota Binjai adalah sektor listrik, gas dan air bersih; konstruksi; pengangkutan dan komunikasi; dan jasa-jasa. Hasil perhitungan LQ dan shift share menunjukkan bahwa sektor yang potensial dikembangkan di Kota Binjai adalah sektor konstruksi, keuangan dan jasa-jasa (Tabel 6). 
Tabel 6. Sektor yang Potensial Dikembangkan di Kota Binjai

\begin{tabular}{|c|c|c|c|}
\hline \multirow{2}{*}{ Lapangan Usaha } & \multicolumn{2}{|c|}{ Laju Pertumbuhan } & \multirow{2}{*}{$\begin{array}{c}\text { Potensial } \\
\text { dikembangkan } \\
\text { di Kota Binjai }\end{array}$} \\
\hline & LQ & Shift Share & \\
\hline $\begin{array}{l}\text { Pertanian, Peternakan, Kehutanan Dan } \\
\text { Perikanan / Agriculture, Livestock, } \\
\text { Forestry \& Fishery }\end{array}$ & $\begin{array}{l}\text { Sektor non } \\
\text { basis }\end{array}$ & $\begin{array}{l}\text { - Tidak memiliki daya } \\
\text { saing } \\
\text { - Tidak berkembang }\end{array}$ & - \\
\hline $\begin{array}{l}\text { Pertambangan \& Penggalian/ Mining } \\
\& \text { Quarrying }\end{array}$ & Sektor basis & $\begin{array}{l}\text { - Tidak memiliki daya } \\
\text { saing } \\
\text { - Tidak berkembang }\end{array}$ & - \\
\hline $\begin{array}{l}\text { Industri Pengolahan/Manufacturing } \\
\text { Industry }\end{array}$ & $\begin{array}{l}\text { Sektor non } \\
\text { basis }\end{array}$ & $\begin{array}{l}\text { - Tidak memiliki daya } \\
\text { saing } \\
\text { - Tidak berkembang }\end{array}$ & - \\
\hline $\begin{array}{l}\text { Listrik, Gas \& Air Bersih/ Electrity, } \\
\text { Gas \& Water Supply }\end{array}$ & $\begin{array}{l}\text { Sektor non } \\
\text { basis }\end{array}$ & $\begin{array}{l}\text { - Memiliki daya saing } \\
\text { - Berkembang }\end{array}$ & - \\
\hline Konstruksi/Construction & Sektor basis & $\begin{array}{l}\text { - Memiliki daya saing } \\
\text { - Berkembang }\end{array}$ & $\sqrt{ }$ \\
\hline $\begin{array}{l}\text { Perdagangan, Hotel Dan Restoran/ } \\
\text { Trade, Hotel \& Restaurant }\end{array}$ & $\begin{array}{l}\text { Sektor non } \\
\text { basis }\end{array}$ & $\begin{array}{l}\text { - Tidak Memiliki daya } \\
\text { saing } \\
\text { - Tidak Berkembang }\end{array}$ & - \\
\hline $\begin{array}{l}\text { Pengangkutan \& } \\
\text { Komunikasi/Transport \& } \\
\text { Communication }\end{array}$ & $\begin{array}{l}\text { Sektor non } \\
\text { basis }\end{array}$ & $\begin{array}{l}\text { - Memiliki daya saing } \\
\text { - Berkembang }\end{array}$ & - \\
\hline $\begin{array}{l}\text { Keuangan, Real Estat \& Jasa } \\
\text { Perusahaan/Finance, Real Estate }\end{array}$ & Sektor basis & $\begin{array}{l}\text { - Tidak Memiliki daya } \\
\text { saing } \\
\text { - Berkembang }\end{array}$ & $\sqrt{ }$ \\
\hline Jasa-Jasa/Services & Sektor basis & $\begin{array}{l}\text { - Memiliki daya saing } \\
\text { - Berkembang }\end{array}$ & $\sqrt{ }$ \\
\hline
\end{tabular}

\section{Analisis SWOT}

Analisis SWOT digunakan untuk mengetahui strategi apa yang perlu dilakukan menyikapi kebijakan pemerintah melalui RTRW yang menginginkan dua desa di Kecamatan Binjai Utara menjadi kawasan industri. Strategi ini dibuat dengan cara memperhitungkan kekuatan, kelemahan, peluang dan ancaman dari kondisi yang ada terhadap rencana tersebut. Analisis SWOT membandingkan antara faktor eksternal Peluang (Opportunities) dan Ancaman (Threats) dengan Faktor Internal Kekuatan (Strength) dan kelemahan (Weaknesses). Matriks TOWS adalah alat lanjutan yg digunakan utk mengembangkan 4 tipe pilihan strategi: SO, WO, ST dan WT. Kemungkinan strategi ada 4 yaitu maju secara progresif, diversifikasi, mengubah strategi atau strategi bertahan.

Data untuk analisis SWOT didapat dari wawancara aparat setempat seperti Lurah, Kepala Dinas Lingkungan, Dinas Pertanian, dll, dan survey lapangan. Dari hasil observasi dan wawancara ditemukan kekuatan, kelemahan, kesempatan dan ancaman bagi pengembangan Kecamatan Binjai Utara menjadi kawasan industri.

Kekuatan dari rencana pengembangan kawasan industri di Kecamatan Binjai Utara:

1. Sudah ada Perda yang menetapkan kawasan Binjai Utara sebagai Kawasan Industri (Perda No 13 Tahun 2011).

2. Lurah di Kawasan Binjai Utara sangat mendukung kawasan ini menjadi kawasan industri karena penyerapan tenaga kerja dan PAD.

3. Penduduk setempat bersedia bila kawasannya menjadi kawasan industri asalkan limbahnya tidak mengganggu kehidupan masyarakar, seperti air sumur. 
4. Sudah mulai ada industri skala menengah dan kecil yang diusahakan oleh penduduk (sekitar 100 industri).

5. Sawah yang ada di Kecamatan Binjai Utara adalah sawah tadah hujan bukan sawah beririgasi teknis sehingga bisa diubah peruntukannya.

6. Kota Binjai tidak jauh dari Medan (sekitar 1,5 jam perjalanan darat). Oleh sebab itu, lokasi bisa disebut strategis karena dekat dengan pasar (Kota Medan) dan pelabuhan Belawan.

Kelemahan dari rencana pengembangan kawasan industri di Kecamatan Binjai Utara:

1. Masih rendahnya tingkat pendidikan masyarakat setempat.

2. Masih kurangnya infrastruktur (drainase, jalan) di Kecamatan Binjai Utara.

3. Kawasan ini dilewati SUTET.

4. Tanah di kawasan ini belum dikuasai oleh pemerintah.

Peluang dari rencana pengembangan kawasan industri di Kecamatan Binjai Utara adalah rencana dibukanya pintu tol ke arah Pelabuhan Belawan dimulai dari kecamatan Binjai Utara sehingga pemasaran dan pembelian bahan baku bisa semakin luas. Terutama menghubungkan Propinsi Aceh dengan Kota Medan dan Belawan. Peluang mendapatkan bahan baku dari Aceh dan pemasaran ke Kota Medan, Aceh atau pelabuhan Belawan semakin luas. Rencana ini sudah memasuki tahap AMDAL. Lebih jelasnya dapat dilihat Gambar 11.

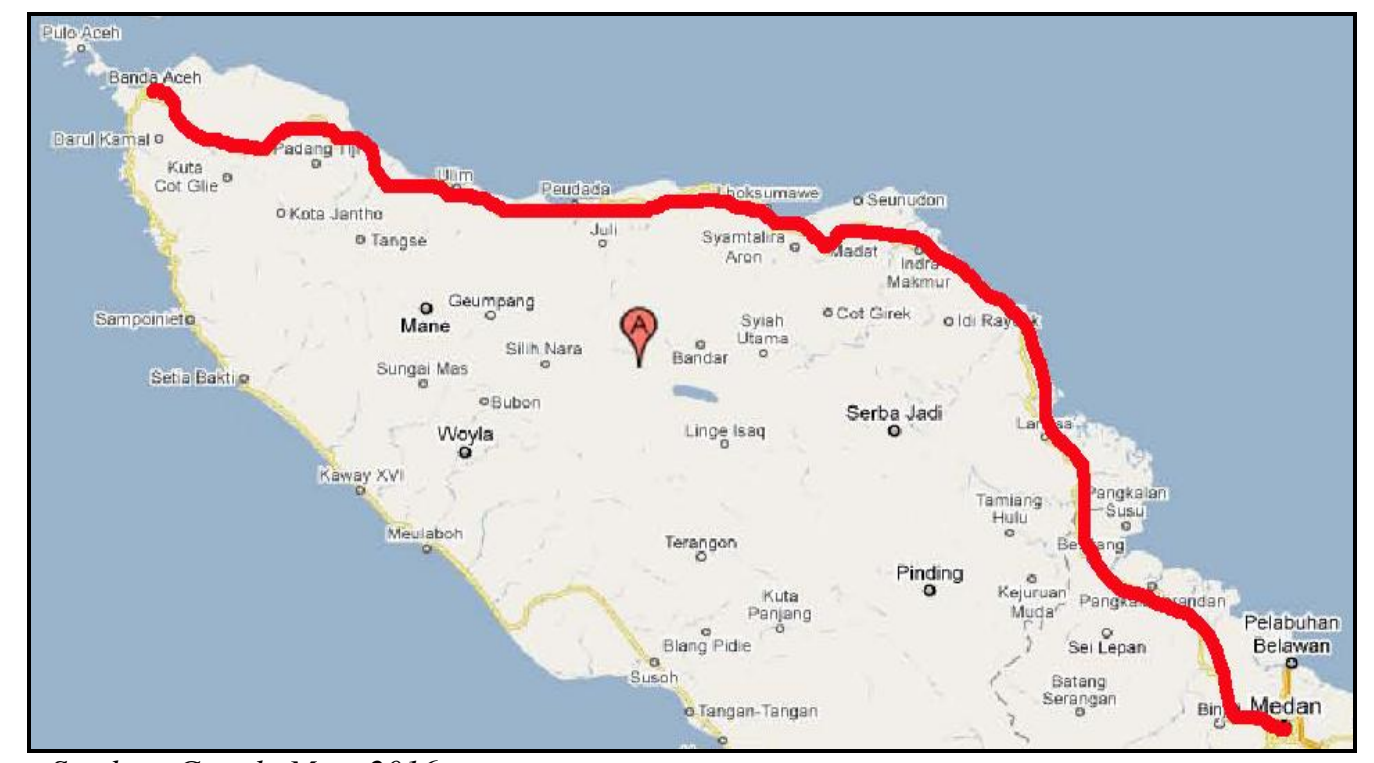

Sumber: Google Map, 2016

Gambar 11. Jalan Nasional yang Menghubungkan Banda Aceh dan Kota Medan

Ancaman dari rencana pengembangan kawasan industri di Kecamatan Binjai Utara:

1. Tanah sudah mulai dibeli oleh para calo tanah untuk mengambil keuntungan dari rencana perubahan guna lahan dari pertanian ke industri.

2. Kecamatan Binjai Utara adalah penghasil tanaman pangan terbesar di Kota Binjai. Bila terjadi perubahan guna lahan, maka Binjai akan bergantung kepada pembelian bahan pangan dari luar.

Tabel 7 menunjukkan hasil perhitungan bobot dan skor dari peluang, ancaman, kekuatan dan kelemahan di atas. 
Tabel 7. Perhitungan Bobot dan Skor SWOT

\begin{tabular}{l}
\hline KEKUATAN \\
\hline Sudah ada Perda yang menetapkan kawasan Binjai \\
Utara sebagai Kawasan Industri (Perda No 13 Tahun \\
2011) \\
Lurah di Kawasan Binjai Utara sangat mendukung \\
kawasan ini menjadi kawasan industri karena \\
penyerapan tenaga kerja dan PAD. \\
Penduduk setempat bersedia bila kawasannya menjadi \\
kawasan industri asalkan limbahnya tidak mengganggu \\
kehidupan (misalnya air sumur, dll) mereka. \\
Sudah mulai ada industri skala menengah dan kecil \\
yang diusahakan oleh penduduk (sekitar 100 industri). \\
Sawah yang ada di Kecamatan Binjai Utara adalah \\
sawah tadah hujan. \\
Kota Binjai tidak jauh dari Medan (sekitar 1,5 jam \\
perjalanan darat). Oleh sebab itu, lokasi bisa disebut \\
strategis karena dekat dengan pasar (Kota Medan) atau \\
pelabuhan Belawan.
\end{tabular}

\section{KELEMAHAN}

Masih rendahnya tingkat pendidikan masyarakat setempat.

Masih kurangnya infrastruktur (drainase, jalan) di Kecamatan ini.

Kawasan ini dilewati SUTET

Tanah di kawasan ini belum dikuasai oleh pemerintah.

TOTAL

Rencana dibukanya pintu tol ke arah Belawan dimulai dari kecamatan ini sehingga pemasaran dan pembelian bahan baku bisa semakin luas. Rencana ini sudah memasuki tahap AMDAL.

Peningkatan PAD Kota dari hasil industri

TOTAL

\section{ANCAMAN}

Tanah sudah mulai dibeli oleh para calo tanah untuk mengambil keuntungan dari rencana perubahan guna lahan dari pertanian ke industri.

Kecamatan Binjai Utara adalah penghasil tanaman pangan terbesar di Kota Binjai. Bila terjadi perubahan guna lahan, maka Binjai akan bergantung kepada pembelian bahan pangan dari luar.

\begin{tabular}{|c|c|c|}
\hline SKOR (1-10) & BOBOT (1-5) & TOTAL \\
\hline 10 & 5 & 50 \\
\hline 7 & 4 & 28 \\
\hline 7 & 4 & 28 \\
\hline 5 & 2 & 10 \\
\hline 8 & 3 & 24 \\
\hline 8 & 4 & 32 \\
\hline $\begin{array}{c}\text { SKOR (1-10) } \\
8\end{array}$ & $\underset{5}{\text { BOBOT }}(1-5)$ & $\begin{array}{c}172 \\
\text { TOTAL } \\
40\end{array}$ \\
\hline 8 & 5 & 40 \\
\hline 8 & 5 & 40 \\
\hline 5 & 3 & $\begin{array}{c}15 \\
135\end{array}$ \\
\hline $\mathbf{N}(X)$ & & 37 \\
\hline $\begin{array}{c}\text { SKOR (1-10) } \\
4\end{array}$ & $\begin{array}{c}\text { BOBOT (1-5) } \\
5\end{array}$ & $\begin{array}{c}\text { TOTAL } \\
20\end{array}$ \\
\hline 7 & 5 & $\begin{array}{l}35 \\
\mathbf{5 5}\end{array}$ \\
\hline $\begin{array}{c}\text { SKOR (1-10) } \\
8\end{array}$ & $\underset{5}{\text { BOBOT }}(1-5)$ & $\begin{array}{c}\text { TOTAL } \\
40\end{array}$ \\
\hline 10 & 5 & 50 \\
\hline
\end{tabular}

90

Dari analisis SWOT pada Tabel 7 dapat dilihat bahwa posisi strategi berada di kuadran II (37,-35), sehingga harus dilakukan diversifikasi strategi untuk pengembangan kawasan industri di Kecamatan Binjai Utara. Diversifikasi strategi adalah merupakan strategi untuk beralih ke industri yang berbeda atau menghasilan produk yang berbeda/bervariasi. Peralihan ke industri yang lain bisa pada indutri yang menghasilkan produk yang terkait dengan produk lama (produk saat ini) atau menghasilkan produk yang tidak terkait dengan produk sebelumnya (produk saat ini). 
Diversifikasi strategi yang bisa dilakukan di Binjai Utara adalah industri yang dikembangkan di kawasan industri Binjai Utara adalah:

1. Industri pengolahan hasil pertanian yang memang banyak dihasilkan di Binjai Utara seperti industri pengolahan padi sawah, jagung, kacang tanah, kacang hijau, kacang panjang, dan lainnya. Walau pertanian bukan sektor basis, tidak kompetitif, namun hasil pertanian paling banyak dihasilkan di kecamatan ini dibandingkan kecamatan lainnya.

2. Industri yang mendukung potensi daerah Kota Binjai seperti industri pengolahan hasil pertambangan dan penggalian, dan industri yang mendukung sektor konstruksi, misalnya industri batako, industri kusen, industri bahan bangunan, dan lainnya.

Posisi kuadran yang menunjukkan rencana pengembangan kawasan industri Binjai Utara tergambarkan di Gambar 12.

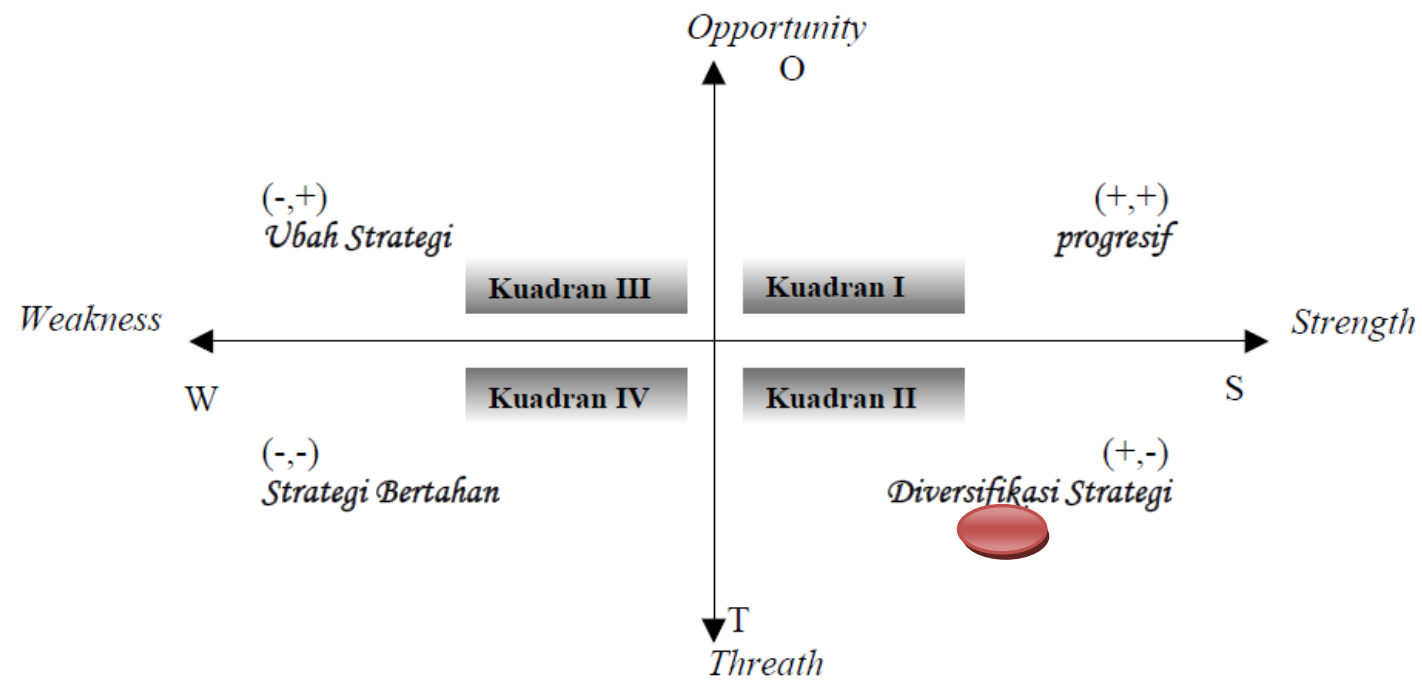

: Posisi hasil analisis SWOT

Gambar 12. Posisi Kuadran Rencana Pengembangan Kawasan Industri Binjai Utara

\section{Kesimpulan}

Kesimpulan dari penelitian ini adalah:

1. Berdasarkan analisis LQ, dapat dilihat bahwa sektor di Kota Binjai yang hasilnya dapat dijual ke luar daerah adalah sektor pertambangan dan penggalian, sektor konstruksi, sektor keuangan dan jasa. Sektor pertambangan tentu saja dihasilkan dari pertambangan gas yang dikelola oleh PT Pertamina. Dari analisis LQ dapat dilihat bawah hasil dari sektor industri pengolahan belum bisa diekspor ke luar Kota Binjai. Oleh sebab itu disimpulkan bahwa Kota Binjai belum siap bila mengembangkan sektor industri high tech seperti yang dicanangkan di RTRW.

2. Namun, sesuai dengan kebijakan RTRW, sektor jasa dapat dikembangkan di Kota Binjai karena jasa adalah salah satu sektor unggulan di Kota Binjai, pekerja di sektor fomal banyak bekerja di bidang jasa kemasyarakatan dan perdagangan, pekerja di sektor informal juga banyak bekerja di bidang jasa.

3. Hasil analisis shift share menunjukkan bahwa nilai keunggulan kompetitif yang bernilai positif di Kota Binjai adalah sektor listrik, konstruksi, pengangkutan dan jasa- 
jasa. Hal ini berarti sektor-sektor ini memiliki keunggulan komparatif atau siap bersaing dengan kabupaten atau kota lain di Sumatera Utara. Bila dilihat dari pergeserannya, sektor yang bergerak progresif di Kota Binjai adalah sektor listrik, konstruksi; pengangkutan; keuangan dan jasa-jasa. Dari analisis ini dapat dilihat bahwa sektor industri di Kota Binjai belum siap bersaing dengan sektor industri di kabupaten atau kota lain di Sumatera Utara dan belum bergerak secara progresif. Sektor pengangkutan akan semakin maju dengan adanya pembangunan jalan tol Medan-Binjai yang pintu masuk dan keluarnya berada di Kecamatan Binjai Utara.

4. Dari analisis SWOT dapat dilihat bahwa perlu dilakukan diversifikasi strategi untuk mengembangkan kawasan industri Binjai Utara. Apabila tetap ingin mengembangkan kawasan industri, maka industri yang dikembangkan adalah:

a. Industri pengolahan hasil pertanian karena pertanian banyak dihasilkan dari Kecamatan Binjai Utara (walau hanya pertanian tadah hujan, namun memberi hasil yang besar)

b. Indutri pengolahan gas bumi

c. Industri bahan bangunan untuk mendukung sektor konstruksi

d. Industri alat-alat transportasi untuk mendukung sektor pengangkutan

e. Industri jasa transit untuk memanfaatkan posisi strategis Kecamatan Binjai Utara terhadap Aceh dan Kota Medan (khususnya pelabuhan Belawan)

5. Industri pergudangan terpadu semula diharapkan bisa dikembangkan untuk memanfaatkan posisi strategis Kecamatan Binjai Utara yang akan menjadi pintu masuk tol bagi kendaraan dari Aceh menuju Pelabuhan Belawan dan Medan, dan sebaliknya. Namun cikal bakal atau potensi pergudangan terpadu ini sedikit sekali di Kecamatan Binjai Utara. Industri jasa yang tepat dikembangkan untuk memanfaatkan potensi strategis ini adalah pengembangan kawasan transit seperti pengembangan rest area, parkiran kendaraan, hotel atau tempat menginap sementara, terminal tempat berganti moda, pusat perbelanjaan, pelayanan perbankan, dan lainnya.

\section{Daftar Pustaka}

Adisasmita, R. (2014). Pertumbuhan wilayah dan wilayah pertumbuhan. Yogyakarta: Graha Ilmu.

Amalia, F. (2012). Penentuan sektor unggulan perekonomian wilayah Kabupaten Bone Bolango dengan pendekatan sektor pembentuk PDRB. Jurnal Etikonomi, 11(2), 196-207.

Arsyad, L. (2005). Pengantar perencanaan dan pembangunan ekonomi daerah (Edisi Kedua). Yogyakarta: BPFE.

Badan Pusat Statistik Kota Binjai. (2015). Statistik daerah Binjai Barat tahun 2015. Kota Binjai: BPS Kota Binjai.

Badan Pusat Statistik Kota Binjai. (2015). Statistik daerah Binjai Kota tahun 2015. Kota Binjai: BPS Kota Binjai.

Badan Pusat Statistik Kota Binjai. (2015). Statistik daerah Binjai Selatan tahun 2015. Kota Binjai: BPS Kota Binjai.

Badan Pusat Statistik Kota Binjai. (2015). Statistik daerah Binjai Timur tahun 2015. Kota Binjai: BPS Kota Binjai.

Badan Pusat Statistik Kota Binjai. (2015). Statistik daerah Binjai Utara tahun 2015. Kota Binjai: BPS Kota Binjai.

Badan Pusat Statistik Kota Binjai. (2014). Indikator ketenagakerjaan Kota Binjai 2014 . Kota Binjai: BPS Kota Binjai.

Fattah, S., \& Rahman, A. (2013). Analysis of regional economic development in the regency/ municipality at South Sulawesi Province in Indonesia. Journal of Economics and Sustainable Development, 4(1), 1-9.

Klosterman, R. E. (1990). Community analysis and planning techniques. USA: Rowman \& Littlefield Publishers, Inc.

Kuncoro, M. (2011). Perencanaan daerah: Bagaimana membangun ekonomi lokal, kota dan kawasan. Jakarta: Salemba Empat. 


\section{Menemukan Strategi Pengembangan Kawasan Industri Melalui Analisis Sektor Unggulan Kota Binjai}

Pemerintah Kota Binjai. (2011). Peraturan Daerah Kota Binjai Nomor 12 Tahun 2011 tentang Rencana Tata Ruang Wilayah Kota Binjai Tahun 2011-2030. Kota Binjai: Pemerintah Kota Binjai.

Rangkuti, F. (2005). Analisis SWOT teknik membedah kasus bisnis. Jakarta: PT. Gramedia Pustaka.

Titisari, K. H. (2010). Identifikasi potensi ekonomi daerah Boyolali, Karanganyar dan Sragen. Jurnal Ilimiah Orasi Bisnis, 4, 9-27.

Utomo, S. H. (2011). Analisis sektor unggulan perekonomian daerah (Studi pada komoditi unggulan di Kecamatan Bumiaji, Kotamadya Batu. Jurnal Aplikasi Manajemen, 9(2), 394-412.

Widodo, T. (2006). Perencanaan pembangunan: Aplikasi komputer. Yogyakarta: UPP UMP YKPN. 